Marco Boffi, Eleonora Riva, Nicola Rainisio

\title{
7 Positive Change and Political Participation: Well-Being as an Indicator of the Quality of Citizens' Engagement
}

\begin{abstract}
Political participation has long been considered as a source of benefits for the community. Its role in the evolution of society has been assessed through diverse social indicators, from which well-being has been assigned a central position. In this chapter we look at the historical progress of such indicators, highlighting the contribution of psychology. We suggest that a eudaimonic perspective can explain the link between individuals' well-being and participation. In particular flow can be used as referential theory to describe mechanisms affecting both personal growth and social context, resulting in an inspiring notion to design participative settings.
\end{abstract}

Keywords: Well-Being; Citizen Participation; Quality of Life; Flow of Consciousness; Quality of Participation; Social Indicators; Eudaimonia; Subjective Well-Being

\subsection{Envisioning Better Societies: Concepts and Measures for a Positive Change}

Political participation is often seen as a main goal for modern democracies, in consideration of its positive relation with diverse dimensions of our lives such as wealth, health or education (Field, 2003; Halpern, 2005). Hence the decline faced by traditional forms of participation (e.g. Gray \& Caul, 2000) has been considered as a warning sign for the future development of our societies. Yet the role of political participation in creating a positive change is not so straightforward, and we need awareness regarding the quality of participation as well as the quantity. In this chapter we consider how well-being, among other social indicators, has been used to inform society at large about the direction of its progress. Indeed, different conceptions of well-being will highlight different qualities of participation. To this end, the evolution of positive psychology is looked upon as resulting from a long multidisciplinary path devoted to exploring the notion of well-being within societies, while featuring connections with some major social changes. We aim to emphasize the contribution of the eudaimonic perspective, suggesting how flow of consciousness can be fruitfully integrated to understand participatory behaviors. 


\subsubsection{The Evolution of the Concept of Quality of Life}

The ambition for a positive change of society is portrayed well by the notion of Quality of Life (QoL), which has become increasingly important in the public debate of industrialized Western societies since the '60s. The very nature of QoL is extremely heterogeneous, including environmental, social and political concerns. As emphasized by Rapley (2003), the focus of attention can vary from a macroscopic to a microscopic level. The latter is well represented by psychological studies on well-being, but it is also important to briefly take into account the former in order to fully comprehend the political value of the issue in general.

Since its inception, QoL has been closely related to the development of social indicators, conceived as statistical measures designed to monitor the progress of issues and phenomena of central importance to human well-being (OECD, 1976). Since the early works by William Ogburn, published in the American Journal of Sociology, the goal has been to analyze regularities underlying the dynamics of industrialized societies. Given the historical and cultural context, the indicators had a mainly economic nature: the effort of monetizing as many dimensions as possible aimed to build a quantitative description of reality. In this context Kuznets created the Gross Domestic Product index (GDP), measuring the value of goods and services produced in a country in a given period of time (1934). Although the author had highlighted that GDP per capita can only serve as a generic indicator of economic standards of living, it quickly established itself both as a measure of welfare in general and of the very notion of development. The reaction to the implementation of such economic measures was not long in coming. Refusing to assess QoL mainly through a mercantile measure was not simply and academic debate, but a proper cultural stance:

The early stages of social indicators research did not only exert an enormous scientific influence, but these activities were also undertaken with a strong sense of commitment and a sense of mission and thus became well known as the 'social indicators movement' (Noll, 2004, p. 152).

The debate was not simply about GDP itself or the use made of it, to a broader extent it concerned the privileged role of economists to the detriment of other cultural actors in selecting the information to be used by political decision makers. It is indeed a crucial issue, as the information selected to be monitored can then shape not only political decisions, but also the public perception about what is relevant in a society. This perspective provides understanding to the famous speech given by Robert F. Kennedy when he declared that GDP "measures everything, in short, except that which makes life worthwhile. And it can tell us everything about America except why we are proud that we are Americans" (1968, p. 5). Such a strong spirit of change, in the country that more than others was embracing capitalism, has favored the study of alternative measures. From the beginning the research has been characterized by a continuum between two opposing poles that are still present nowadays (Noll \& Zapf, 1994). On 
the one hand there is the American approach characterized by a mainly psychological background and therefore more sensitive to the individual and their subjectivity, which produced the etymological shift from the notion of welfare to that of well-being. On the other hand is the Scandinavian tradition rooted in sociological studies, which focused on the objective resources available to the individual and which were defined in terms of "money, property, knowledge, psychic and physical energy, social relations, security and so on" (Erikson \& Uusitalo, 1987, p. 189). As clarified by Erikson, they tried to

[...] assess the individual's level of living in a way which makes it as little influenced as possible by the individual's evaluation of his own situation. This seems all the more natural as the individual's level of living is to a large extent based on his 'command over resources', resources which can be used for the ends which he himself finds most satisfactory (1993, p. 77).

\subsubsection{Change Through Knowledge}

For the purposes of the present chapter we want to stress two main aspects of current efforts towards a positive change in society, as embodied by the QoL approach. First of all the role of such measures - regardless of their nature, i.e. objective, subjective, economic, psychological - is not to provide decision makers with immediate practical guidance for every single issue arising in daily practice. Be it GDP or a happiness assessment, social indicators cannot be used as the gasoline warning light, which entails a single predetermined action. As a result of the adjustment of expectations (Innes, 1990) and the systematization of knowledge (Andrews, 1990), a new awareness about the role of social indicators has been established:

A system of social reporting has several functions, the most important of which is to inform the general public. In a democracy, social reporting has a very special function; it is to inform the citizens about the prevailing living conditions in their society and give them a perspective on national development by comparing this with developments in other countries. Democracy assumes that the citizens have access to such knowledge in order to be able to challenge the government, discover new welfare problems and bring alternative solutions to a decision stage by means of political parties and organizations. Accordingly, social reporting has a very special role in society's production of information; it belongs to the democratic infrastructure and has a special political function. To put it simply, social reporting places welfare issues on the political agenda. It supplies material to the public debate, influences the media and, indirectly, the administration. The two objectives - policy analysis and public information - might in practice be implemented within the same system, but they might lead to different reporting programmes, if only one objective is adopted. Different audiences look for and need different kinds of information, and their demands may sometimes clash. Social reporting as public information clearly has a critical function, not restricted to issues of daily planning, and covers a much larger field than policy analysis. This critical function may be highly controversial in unstable political situations and in times of economic crisis (Vogel, 1989, p. 441). 
Secondly, these indicators are not conceived as autonomous instruments built in an abstract neutral space. They are seen as culturally determined tools, whose theoretical background must not only be declared but even developed to provide perspective on complex phenomena (see Allardt, 1993; Lane, 1996). This conceptual change enriches the notion of QoL and discloses the difficulty of finding a unique definition for it (Brown, 2000; Cummins, Gullone, \& Lau, 2002; Felce \& Perry, 1995). Notwithstanding the academic debates about its ambiguity as a scientific notion, Fahey, Nolan and Whelan (2003) emphasize the QoL elements on which there is general agreement and that are conveyed to social and political stakeholders. To begin with, broader information about the social and economical environment is useful to contextualize individual and subjective data, which remain an essential component. This brings the consideration of QoL as a multidimensional concept, which therefore requires a multidisciplinary approach to its understanding, despite there being some critical positions of this approach, (see Cummins, 1996; Veenhoven, 1996). Finally, multidimensionality requires not only the different aspects to be taken into account, but also the assessment of the relationship between them. As a result of these three factors, the measurement of QoL is by mutual agreement conceived as the combination of objective measures (e.g. family attributes, environmental features, employment rate, level of schooling) and subjective indicators related to these dimensions (e.g. satisfaction with family relationships, sense of community, job satisfaction, self-efficacy).

\subsection{The Political Role of Well-Being Studies}

Within the described framework, a number of studies have revolved around the benefits of being politically active, with the aim of including measures of such behaviors in QoL appraisal. In western societies a positive prejudice towards participation is largely influenced by an Aristotelian conception of human nature, as in his view political action is the fulfillment of a shared innate inclination. Social sciences have looked for empirical support for such a perspective on three levels.

1. First, participation reduces the distance between citizens and institutions, making the latter more responsive to collective needs and enhancing objective living conditions (see Erikson, 1993; Wandersman \& Florin, 2000).

2. Second, it improves well-being at a collective level exerting a positive effect on social cohesion and quality of democracy (Putnam, 2000), for example strengthening sense of community (see Obst, Smith, \& Zinkiewicz, 2002).

3. Third, it is a source of individual well-being, subjectively perceived only by those directly involved in participatory behaviors. Participation, then, is important not only because of the goals it pursues, it is intrinsically valuable.

The last level of investigation has been examined by positive psychology, the results of which can be presented in reference to the two main philosophical traditions in well- 
being research: hedonism and eudaimonism. Delle Fave, Massimini and Bassi (2011) effectively summarize some key points distinguishing these two positions. To begin with, hedonism conceives well-being as a state of homeostatic balance addressed to satisfy individual needs, whereas eudaimonism focuses on the process of complexity enhancement leading to it. Hedonism, then, defines well-being as a subjectively felt presence of positive affect and absence of negative affect, whilst eudaimonism emphasizes the active role of the individual in pursuing opportunities for growth. Lastly, hedonic well-being is an individual dimension to be fulfilled also through the community, while in contrast eudaimonic well-being is a primarily collective and shared factor. It is fundamental to consider both aspects, since "hedonic and eudaimonic foci are both overlapping and distinct and [...] an understanding of well-being may be enhanced by measuring it in differentiated ways" (Ryan \& Deci, 2001, p. 148). Nevertheless, beyond the strictly scientific domain, these two different traditions also imagine different relations with the rest of the society.

\subsubsection{The Hedonic Level: Complementing the Political Agenda}

Hedonic well-being is a wide philosophical concept, even though scientific reviews about its origins, especially when in comparison with eudaimonia, often exacerbate some aspects for the sake of clarity. If to a certain extent "hedonistic happiness can occur with no effort-sitting on the couch watching TV, one hand on the remote, and the other in a bag of chips" (King, Eells, \& Burton, 2002, p. 37), examining in depth specific theories can offer a more complex picture. For example, Bentham's hedonic calculus (1996) takes into account seven aspects of pleasure, including extent (actions whose pleasure affects a higher number of people are to be preferred) and duration (temporary pleasure is less valuable than long-term results). Hence, also hedonically one could prefer to volunteer rather than idling in front of the TV. Yet, "although there are many ways to evaluate the pleasure/pain continuum in human experience, most research within the new hedonic psychology has used assessment of subjective wellbeing” (Ryan \& Deci, 2001, p. 144). Subjective well-being (SWB) itself is a multifaceted concept (see Kim-Prieto, Diener, Tamir, Scollon, \& Diener, 2013) often identified with the idea of "happiness": it represents people's evaluation of their own lives, including cognitive and emotional components (Diener, 2009), and nowadays is often considered one of the most popular contributions from psychology to QoL studies.

Two reasons cited by Veenhoven (1991) for choosing such a construct, namely having a punctual definition and consequently a greater ease in measurement, have proved fundamental for the success of SWB, especially if utilized to inform political decision makers. Undoubtedly the choice of reducing the width of the definition of well-being, drawing the attention to partial components (e.g. satisfaction about life circumstances, positive affect, global evaluations), can be scientifically fruitful in that narrower constructs are simpler in their theoretical explanation and empirical 
assessment. Nevertheless we wonder what is actually conveyed by such constructs once they migrate through different disciplines - e.g. philosophy, psychology, sociology, economics, political science - and are finally received by politicians and the general public. We completely recognize diverging definitions as a healthy diversity and not a flaw, but this entails that, despite the robustness of each definition, considered in its entirety the notion of SWB is much less homogeneous and stable than it is initially perceived to be (Duncan, 2013). As for assessment tools, greater ease in measurement doesn't reduce conceptual diversity, but surely favors the spread of such measures which are often brief and quick to be administered. In this perspective, the difficulties faced by policy makers when choosing for the allocation of limited resources to different, non-comparable domains (e.g. economic growth versus environmental quality) can be easily solved by appraising how they affect SWB and deciding accordingly, moving "beyond a total reliance on intuition and ideology" (Diener, Lucas, Schimmack, \& Helliwell, 2009, p. 55). In our view, such asserted neutrality underplays the varied definitions underlying the general concept of SWB or happiness, which can reach incomparability when encompassing non-western concepts: for example, the Buddhist notion of happiness applied in Bhutan as policy indicator advocates detachment from the material world, hence being much closer to the Greek idea of ataraxia than to the goal of pleasure fulfillment (Mancall, 2004). In sum, we argue that in contrast with the concern for raising awareness in the general public (Pavot \& Diener, 2004), presenting SWB indicators as purely non-ideological instruments would recreate the preconditions for the kind of misunderstanding and misuse that occurred with GDP.

Considering such cautions, it is important to highlight how hedonic measures have greatly contributed to the success of subjective assessments. The very features discussed above have effectively complemented the political agenda, favoring the cultural shift towards psychological appraisals. Exemplar is the case of Easterlin paradox (Easterlin, 1974), which proves how the percentage of very happy people in the US didn't increase from the '40s to the '70s, notwithstanding the dramatic economic growth. Similar approaches have opened the way to a large amount of studies showing that national productivity is relevant to happiness as far as it gives access to the fulfillment of basic needs, but once such a break-even point is reached its increase is "not accompanied on average by invariant increases in SWB" (Diener \& Oishi, 2000, p. 204). If not all scholars have come to argue that "happiness was significantly and negatively related to income, and happiness growth was significantly and negatively related to income growth" (Kenny, 1999, p. 15), there is at least large consensus about the fact that the richer the national context is, the less strong the relation between wealth and happiness is (Diener \& Oishi, 2000). Indeed, evidence suggests that people are not conscious of such an effect and overestimate the importance of money for our happiness (Aknin, Norton, \& Dunn, 2009), presumably also because they are prone to spending it in the wrong way (Frank, 2004). 
Among the dimensions studied in relation to happiness, particular attention is devoted to prosocial behaviors, which can provide more significant increases in wellbeing. A number of studies has shown this effect both with correlational methods (Lucas, 2001; Meier \& Stutzer, 2008; Williams \& Shiaw, 1999) and experiments highlighting the direction of causal effects (Aknin, Sandstrom, Dunn, \& Norton, 2011; Lyubomirsky, Sheldon, \& Schkade, 2005). This research is even more politically relevant in as much as SWB, in wealthier countries with higher levels of education, is more strongly correlated with political freedom - conceived as the absence of restrictions on directly participating in the political system thanks to civic and political rights like freedom of speech or free elections - than with economic freedom (Veenhoven, 2000). The importance of developing a public space where citizens can engage themselves for the community's interest has been thoroughly analyzed by Stutzer and Frey, who have made the effort to use hedonic categories to portray eudaimonic concepts by using the notion of procedural utility, that is "the non-instrumental pleasure and displeasure of a process as opposed to the consequences" (2006, p. 393). The authors have focused on Switzerland, which supports direct participation via popular referenda with conditions varying among the different cantons. Research has shown that general happiness is greater with direct access to decision-making practices in comparison to other socio-demographic variables (Frey \& Stutzer, 2002a). Disentangling the different dimensions of the notion of utility, they highlight that people derive procedural utility from directly engaging in political issues, irrespective of the outcome utility obtained (Frey \& Stutzer, 2000; 2002b). These reflections point out that citizens cannot be considered as mere end users of well-being, but rather as players actively involved in its creation. This leads us to the eudaimonic perspective.

\subsubsection{The Eudaimonic Level: Imagining New Perspectives}

If the implementation of hedonic measures is problematic, then the eudaimonic tradition is no less so.

It could be that the apparent disagreement about eudaimonia stems from the philosophical ambiguity of the concept. A variety of authors have interpreted Aristotle's original writings and, for scientific purposes, clearly, there is not sufficient consensus to treat this concept as a singular variable. [...] it becomes clear that, to date, there remain serious problems in the translation of eudaimonia from philosophy to psychology (Biswas-Diener, Kashdan, \& King, 2009, p. 209).

This severe judgment draws attention to two relevant aspects. Firstly, the role of Aristotle is crucial to modern scientific reflections regarding eudaimonia, even to the extent that the contribution of other philosophers, such as Plato, is underplayed (Grinde, 2012). Secondly, the difficulty of accomplishing the passage of eudaimonia from philosophic principles to psychological constructs has given rise to multiple theories, which emphasize different factors underlying wellbeing and are usually 
accompanied by articulated assessment instruments. For example, Ryff defines Psychological Well-Being referring to six facets (self-acceptance, positive relations with others, autonomy, environmental mastery, purpose in life, and personal growth) (Ryff \& Keyes, 1995), whereas the Self-Determination Theory focuses on the importance of satisfying three basic needs, namely competence, relatedness, and autonomy (Deci \& Ryan, 2000). Such variety is actually seen as a generative resource for the whole debate on well-being (Waterman, 2008), especially considering the earlier stage of eudaimonic approach compared to hedonic research. Indeed such complexity is considered necessary, as it is "costly for psychology to equate rigor with an absence of theory, complexities or abstractions” (Ryan \& Huta, 2009, p. 202).

This last stance on the role and features of eudaimonia entails two fundamental consequences. The first is scientific, and posits that the call for a "Big One" conception of well-being (Kashdan, Biswas-Diener, \& King, 2008) is not only premature but also undesirable, in that feeling good (hedonism) and functioning well (eudaimonia) are conceptually and empirically distinct (Keyes, 2006; Keyes \& Annas, 2009; Waterman, Schwartz, \& Conti, 2008). The second is political, in so far as the political use of eudaimonic knowledge in fostering a positive social change is concerned. As formerly discussed, the notion of QoL altogether is an elusive concept considered "among the most inconsistently used terms within the human sciences” (Cummins, Gullone, \& Lau, 2002, p. 8). Yet, this did not prevent it from exerting a decisive influence in different sectors of society during the last few decades. At the same time, although methodologically more homogeneous, SWB measures have proven not to be directly translatable in specific policy goals or governmental actions (Duncan, 2013; Frey \& Gallus, 2013; Thin, 2011). Hence it appears that scientific uniformity is not the most relevant feature to provide government with what is necessary, that is an effective feedback on the delivered programmes. We agree with those scholars advocating a more influential role of psychosocial scientists in such informative function (Diener \& Diener, 2011), but the assumed neutrality of the hedonic approach alone does not seem the most effective means. We argue that to pursue this goal it is necessary to call for explicit recognition of the ultimately political mission of some branches of psychology - aimed in the first place at community psychology but to be extended to positive psychology - and to accordingly redesign its practices by directly engaging in the field (Burton, Kagan, \& Duckett, 2013). What is most needed by social actors involved in such a dialogue towards a positive change alongside the academic community, whether they are politicians, associations, or communities, is not only a variety of social indicators but above all a vision of society that allows them to imagine a genuinely new perspective. In our view here is the added value of eudaimonic theories, which provide a highly meaningful context for the proposed instruments. From this point of view, the search for well-being is mainly a wide cultural project aimed at changing values, as in Kasser's proposal of building an alternative to materialism (2011). Yet, it appears that "efforts to broadly implement the solutions have been largely uncoordinated, as there exists no central organizing body [...] to conceptually unify the many disparate 
antimaterialistic activities in which people have engaged” (Kasser, 2006, p. 204). If it is true that no eudaimonic theory in particular has succeeded in fulfilling such an organizational function to this day, we propose the example of the Degrowth Movement widespread in many European countries, which promotes equality, community conviviality and the reduction of the ecological footprint (see Fournier, 2008; Kallis, 2011; Latouche, 2007). Its proposal of a society, aimed at re-politicizing the role of economics to subordinate it to democracy and citizenship, has successfully structured a eudaimonic concept of well-being capable of transforming theoretical reflections in concrete institutional and political initiatives. Far from considering the Degrowth as the ultimate recapitulation of eudaimonic principles, we see in this phenomenon one of many fulfillments of their potential. In the next section we will examine the eudaimonic value of participation, underlining its connections with the flow of consciousness.

\subsection{Personal Development for Social Change: the Role of Flow of Consciousness in Participatory Behaviors}

Community psychology has greatly contributed to the study of how participation can build well-being at both the collective and individual level. Given the very nature of such research, the connections between these two levels are often emphasized; hence, even focusing on the studies devoted to the latter, we can find data fully coherent with a eudaimonic perspective. For instance, Keyes (2003) has developed a model describing five dimensions of social well-being, which effectively depicts some of its individual components as being more strictly interrelated with the social environment. International data has shown that participatory behaviors can positively affect social well-being in some cultural contexts, even though the relation is not cross-culturally demonstrated (Cicognani, et al., 2008).

The literature devoted to specific groups has also highlighted important effects. Developmental research has shown that experiencing power and control, i.e. having the opportunity to actively participate in one's social environment, is conducive to experience of self-determination and self-efficacy, fundamental components of wellbeing (Prilleltensky, Nelson, \& Peirson, 2001). Indeed, the role of participatory behaviors in increasing youth's self-efficacy is confirmed by Smetana, Campione-Barr and Metzger (2006). In a similar fashion, studies on migrants' conditions have illustrated how direct involvement in groups and associations can make them experience a sense of skillfulness, positivity, mastery and purpose (García-Ramírez, Manuel, Paloma, \& Hernández-Plaza, 2011). Through these forms of participation migrants can develop critical thinking and learn to recompose different domains of the self (e.g. gender, social class, political position), regaining a sense of agency to cope with oppressing living conditions. In this perspective they can experience well-being through the perception of socio-political control over their environment (Prilleltensky, 2008). Similar 
conclusions have been drawn with reference to the general population: "participation in social movements frequently involves enlargement of personal identity for participation and offers fulfillment and realization of the self" (Gamson, 1992, p. 56).

Yet, Benford and Snow have noted that "the question of how participation precipitates the enlargement of personal identity [...] has not been satisfactorily answered" (2000, p. 631). We suggest that a fruitful answer to this point can be offered explaining participatory behaviors through Flow of Consciousness (Csikszentmihalyi, 1975/2000). Such a theoretical construct, by virtue of its remarkable connections with the core principles of the eudaimonic approach, accounts for a wide range of phenomena. We aim to explore our proposal at two different levels - the individual and the environment. Indeed the relation between these two components represents the file rouge of eudaimonic well-being stemming from participation. Furthermore, flow itself can be conceived as a theory describing a very high-level interaction between human being and space. Hence, our goal is to offer an explanation of what happens to the individual during political participation and how this can be favored in participatory settings.

The first level to be considered is the most circumscribed, being referred to activists. In many modern societies there is a significant minority of people supporting some public cause by enacting behaviors with a political value (from institutional actions like promoting a political candidate to unconventional initiatives like boycotting). As stated by Wallace and Pichler these

people participate in civil society because they follow a particular enthusiasm which is important for them [...] or because they feel they want to contribute to society [...]. These kinds of enthusiasms and commitments are aspects of life that can lead to self-actualisation in a Maslowian sense (2009, p. 259).

Hence activists involved in participatory activities experience flow, an optimal experience characterized by a sense of engagement and enjoyment (Csikszentmihalyi, 1975/2000). Such characteristics concur to qualify flow as an autotelic experience (Csikszentmihalyi, 1997), which means that its highly rewarding nature drives people to repeat the actions from which it is generated, without any additional external reward. If we imagine the replication of such a mechanism on a daily basis, in the long term it can account for how activists come to determine their own life theme, that is the original and personal set of interests and purposes pursued in a lifetime (Csikszentmihalyi \& Beattie, 1979; Inghilleri, 1999). These two aspects, namely the intrinsic motivation in participating and the self-determination related with it, are key factors to foster individual's well-being. Such a paramount role of intrinsic motivation in participation is consistent with data from Omoto and Snyder (1995), who have demonstrated that more self-oriented volunteers are actively engaged for a longer period as compared to those more altruistically oriented. Consistent with this is the data presented by Klar and Kasser (2009), which suggested that political activism is motivating in itself. Similarly, Meier and Stutzer (2008) have shown that volunteering 
is intrinsically rewarding, as it offers the opportunity to fulfill prosocial aspirations and to engage in challenging tasks.

This last aspect is strictly connected with another key component of flow, the subjective perception that by fully exploiting our skills we can face the challenges set by a specific situation. This sort of high-level balance drives an activist to constantly learn new skills and to test them in contexts characterized by increasing complexity. This dynamic explains how participation positively affects self-efficacy and agency, from the leafleting appointed to beginners to the management of a campaign carried out by experts. Nevertheless, such increases in complexity are not only cognitive: the insurgence of flow entails brief moments of total concentration on the task and loss of self-consciousness, involving in an ordered interaction affective and motivational processes (Csikszentmihalyi, 1990). Then it qualifies itself as a composite holistic growth of the self allowing the integration of new components of identity (Inghilleri, 1999), which explains how participation can produce an enlargement of personal identity (Benford \& Snow, 2000; Gamson, 1992). In addition to theoretical consonances with community psychology constructs, research confirms the recognition of flow in a sample of political activists, accounting for more frequent engagement and more important roles in the group (Boffi, 2012a). We suggest that further development of such monitoring would allow the improved comprehension of the motivational dynamics of participation with a common measure.

The second level of our reflection concerns participatory settings, including all those public spaces open to diverse stakeholders for consultative or deliberative purposes. Such spaces are easily accessed by activists, but in given circumstances they can also attract other cohorts of citizens by means of extrinsic rewards (e.g. improving objective life conditions). In this case the whole group of participants is characterized by varied levels of commitment, depending on how much each individual values participation in general or the specific issue in particular. Hence, properly designing participatory activities is fundamental in order to keep as many citizens as possible involved in the process. Mannarini, Fedi and Trippetti, summarizing the effects of consultative arenas, give prominence to the fact that "positive feelings, and specifically being globally satisfied with the experience, strengthened the willingness of undertaking participatory behaviors in the future. Satisfaction emerged then as a factor of sustainable participation, enabling citizens to persist or transfer participatory behaviors to other settings" (2010, p. 270). We suggest that referring to flow experience to appraise the quality of participatory settings is one step beyond sustainability of participation, as it would allow not only the monitoring of a positive state of satisfaction but rather a real process of flourishing in the individual. Table 7.1 presents in brief the structural analogies between the desired features of a participatory setting able to favor a positive experience and the respective dimension of flow to be monitored. 
Table 7.1: Structural analogies between features of positive participatory settings and dimensions of flow

\begin{tabular}{ll}
\hline $\begin{array}{l}\text { Positive participatory settings - } \\
\text { adapted from (Mannarini, Fedi, \& } \\
\text { Trippetti, 2010) }\end{array}$ & $\begin{array}{l}\text { Characteristics of flow - adapted from (Jackson \& Marsh, } \\
\text { 1996) }\end{array}$ \\
\hline $\begin{array}{l}\text { Accessible } \\
\text { Providing participants with adequate } \\
\text { time and information on the issue at } \\
\text { stake. }\end{array}$ & $\begin{array}{l}\text { Challenge-skill balance } \\
\text { physical activities but also in intellectual and social ones. }\end{array}$ \\
$\begin{array}{l}\text { Sustainable } \\
\text { Smooth relationships resulting in a } \\
\text { general positive feeling. }\end{array}$ & $\begin{array}{l}\text { Positive affect } \\
\text { General positive sensation, to be complemented with the } \\
\text { nransparent }\end{array}$ \\
$\begin{array}{l}\text { nake publicly clear aims and scope "group flow" } \\
\text { of participation. }\end{array}$ & $\begin{array}{l}\text { Clear goals } \\
\text { Identify specific route of action; goals can be immediate or } \\
\text { distant in the future. }\end{array}$ \\
$\begin{array}{l}\text { Effective } \\
\text { Concrete effects in the environment } \\
\text { and the community. }\end{array}$ & $\begin{array}{l}\text { Unambiguous feedback } \\
\text { Closely related to established goals, it allows the regular } \\
\text { monitoring of the effective consequences of executed } \\
\text { actions. }\end{array}$ \\
\hline
\end{tabular}

Finding an adequate way of appraising the environmental attributes conducive to flow is crucial. Indeed, people who are not intrinsically motivated can easily find participation demanding and withdraw if the process is not adequately managed (Kagan, 2006). In such a perspective it is essential to realize what resources must be provided to the citizens in order to grant them access to participation (Cantor \& Sanderson, 1999). In fact, even though flow is intrinsic in nature, it does not mean that it cannot be triggered by extrinsic motivations that become intrinsic during the execution of the task. In other words, if a citizen engages in participation just to obtain a bus-stop closer to their residence, experiencing a positive interaction and a sense of growth can transform their motivation and make them persevere for other broader goals. Since the issue of attracting and motivating non-activists is considered crucial, we also suggest a further move in developing a program to monitor flow in society. It is indeed well known that the activities producing flow vary across different cultural domains (Delle Fave, Massimini, \& Bassi, 2011): diverse socio-cultural contexts prescribe particular life tasks for individuals to pursue, and provide consistent opportunities for them (Cantor \& Sanderson, 1999). If those in charge of promoting participation policies were informed of such a distribution of flow-generating activities in each community, it would be possible for them to design new forms of participation more sensitive to such preferences and more likely to succeed. Indeed, since during the experience of flow the self is prone to including new elements, we expect the spontaneous insurgence of such optimal experience to facilitate an effect of conscientisation, 
that is the acquisition of critical thinking and awareness about oneself and the world (Campbell \& Jovchelovitch, 2000).

\subsection{Conclusions}

In this chapter we aimed to develop a meta-analytical reflection on the role of psychology in studying and informing the society on the importance of political participation. We are of the persuasion that an increased consciousness of the historical function of the psychological discipline can lead to a better use of its knowledge in present communities. Furthermore, we call for a determined stance in fulfilling the mission of positive psychology, which is to overtly interact with other stakeholders in pursuing common well-being.

In presenting the different perspectives we tried to include contrasting voices, being convinced that from this long-time debate useful insights can be derived. Yet, our attention revolved mainly around the eudaimonic approach (see also chapter 1), as we recognize in it the potential to effectively deal with the environmental and social rights issues at stake. Our effort was to depict a wide, multidisciplinary framework for the flow theory, hoping that it can be of inspiration to scholars from other backgrounds as well.

Ultimately, our proposal of integrating flow of consciousness among the measures of political participation aims at encouraging a qualitative observation of this phenomenon. The diminishing engagement of citizens in traditional forms of participation cannot be looked at only in a quantitative perspective. For instance, data has shown how the Italian political system is no more able to offer opportunities of selfdevelopment to its practitioners (Boffi, 2012b), hence it is highly relevant to explore the many reasons behind political withdrawal. Against a general drop in voting turnout, it becomes crucial to understand whether we are facing an informed and critical decision of abstaining from voting or rather a generic loss of interest. On the other side, the same question has to be asked at the emergence of popular "antagonist" movements, to appraise to what extent these represent an aware reaction to system malfunctions instead of a political emotional outburst.

We see a great space for developing such an approach, notwithstanding the methodological difficulties. The recent decision to examine more in depth eudaimonic measures in the European Social Survey (2013) proves the interest for such a wider picture, and once again highlights the need for new instruments. Our proposal in particular offers a demanding challenge to all scholars devoted to flow research. The assessments hypothesized at different levels (i.e. individual, group) requires the evaluation of which tools, among those already existing, can better provide the necessary information, or if new efforts are to be made. Specific attention should be devoted to group dynamics of flow, which we expect to be fruitfully expanded in collaboration with community psychologists. 


\section{References}

Aknin, L. B., Norton, M. I., \& Dunn, E. W. (2009). From wealth to well-being? Money matters, but less than people think. Journal of Positive Psychology, 4, 523-527.

Aknin, L. B., Sandstrom, G. M., Dunn, E. W., \& Norton, M. I. (2011). Investing in Others: Prosocial Spending for (Pro)Social Change. In R. Biswas-Diener, Positive Psychology as Social Change (p. 219-234). Springer Netherlands.

Allardt, E. (1993). Having, loving, being: An alternative to the Swedish model of welfare research. In M. Nussbaum, \& A. Sen (Eds.), The quality of life (p. 88-94). New York: Oxford University Press.

Andrews, F. (1990). Evolution of a Movement. Journal of Public Policy(9), 401-405.

Benford, R. D., \& Snow, D. A. (2000). Framing processes and social movements: An overview and assessment. Annual review of sociology, 26(1), 611-639.

Bentham, J. (1996). An Introduction to the Principles of Morals and Legislation. (J. H. Burns, \& L. A. Hart, Eds.) Oxford: Clarendon Press.

Biswas-Diener, R., Kashdan, T. B., \& King, L. A. (2009). Two traditions of happiness research, not two distinct types of happiness. Journal of Positive Psychology, 4, 208-211.

Boffi, M. (2012a). Flow as a measure of political engagement. ECPP 2012. 6th European Conference on Positive Psychology. 26-29 June, Moscow.

Boffi, M. (2012b). Politicians as cultural selectors: favoring or discouraging youth participation. Human Affairs: Postdisciplinary Humanities \& Social Sciences Quarterly, 22(3).

Brown, R. I. (2000). Quality of life: Challenges and confrontation. In K. Keith, \& R. Schalock, Crosscultural Perspectives on Quality of Life (p. 347-362). Washington: AAMR.

Burton, M., Kagan, C., \& Duckett, P. (2013). Making the psychological political - challenges for community psychology. Global Journal of Community Psychology Practice, 3(4).

Campbell, C., \& Jovchelovitch, S. (2000). Health, community and development: Towards a social psychology of participation. Journal of Community \& Applied Social Psychology, 10(4), 255-270.

Cantor, N., \& Sanderson, C. A. (1999). Life task participation and well-being: The importance of taking part in daily life. In D. Kahneman, E. Diener, \& N. Schwarz, Well-being: The foundations of hedonic psychology (p. 230-243). New York: Russell Sage Foundation.

Cicognani, E., Pirini, C., Keyes, C., Joshanloo, M., Rostami, R., \& Nosratabadi, M. (2008). Social participation, sense of community and social well being: A study on American, Italian and Iranian university students. Social Indicators Research, 89(1), 97-112.

Csikszentmihalyi, M. (1975/2000). Beyond Boredom and Anxiety. San Francisco: Jossey-Bass.

Csikszentmihalyi, M. (1990). Flow: The psychology of optimal experience. New York: Harper \& Row.

Csikszentmihalyi, M. (1997). Finding flow. The psychology of engagement with everyday life. New York: Basic Books.

Csikszentmihalyi, M., \& Beattie, O. (1979). Life themes: A theoretical and empirical explorationof their origins and effects. Journal of Humanistic Psychology, 19, 677-693.

Cummins, R. A. (1996). The domains of life satisfaction: an attempt to order chaos. Social Indicators Research, 38, 303-328.

Cummins, R. A., Gullone, E., \& Lau, A. L. (2002). A model of subjective well-being homeostasis: the role of personality. In R. A. Cummins, E. Gullone, \& A. L. Lau, The Universality of Subjective Well-Being Indicators (p. 7-46). Dordrech: Kluwer Academic Publishers.

Deci, E. L., \& Ryan, R. M. (2000). The "what" and "why" of goal pursuits: Human needs and the self-determination of behavior. Psychological Inquiry, 11, 227-268.

Delle Fave, A., Massimini, F., \& Bassi, M. (2011). Psychological selection and optimal experience across cultures: social empowerment through personal growth. New York: Springer.

Diener, E. (2009). The science of well-being (Vol. 37). Dordrecht, NL: Springer. 
Diener, E., \& Diener, C. (2011). Monitoring psychosocial prosperity for social change. In R. BiswasDiener, Positive psychology as social change (p. 53-71). Springer Netherlands.

Diener, E., \& Oishi, S. (2000). Money and Happiness. In E. Diener, \& E. M. Suh (Eds.), Culture and Subjective Well-being (p. 185-218). Cambridge: Bradford.

Diener, E., Lucas, R. E., Schimmack, U., \& Helliwell, J. F. (2009). Well-Being for Public Policy. Oxford: Oxford University Press.

Duncan, G. (2013). Should happiness-maximization be the goal of government? In A. Delle Fave, The Exploration of Happiness (p. 303-320). Springer Netherlands.

Easterlin, R. A. (1974). Does economic growth improve human lot? Some empirical evidence. In P. A. Davis, \& M. W. Reder, Nation and Households in economic growth: Essays in honour of Moses Abromowitz (p. 89-125). New York: Academic Press.

Erikson, R. (1993). Description of Inequality: The Swedish Approach to Welfare Research. In M. Nussbaum, \& A. Sen (Eds.), The Quality of Life (p. 67-87). Oxford: Clarendon Press.

Erikson, R., \& Uusitalo, H. (1987). The Scandinavian Approach to Welfare Research. In R. Erikson, E. Hansen, S. Ringen, \& H. Uusitalo (Eds.), The Scandinavian Model, Welfare States and Welfare Research (p. 177-193). New York: M.E. Sharpe.

European Social Survey. (2013). Round 6 Module on Personal and Social Wellbeing - Final Module in Template. Retrieved from www.europeansocialsurvey.org: http://www.europeansocialsurvey. org/docs/round6/questionnaire/ESS6_final_personal_and_social_well_being_module_ template.pdf

Fahey, T., Nolan, B., \& Whelan, C. (2003). Monitoring quality of life in Europe. Luxembourg: Office for Official Publications of the European Communities.

Felce, D., \& Perry, J. (1995). Quality of Life: Its Definition and Measurement. Research in Developmental Disabilities, 16(1), 51-74.

Field, J. (2003). Social capital. London: Routledge.

Fournier, V. (2008). Escaping from the economy: the politics of degrowth. International Journal of Sociology and Social Policy, 28(11/12), 528-545.

Frank, R. H. (2004). How not to buy happiness. Daedalus, 133, 69-79.

Frey, B. S., \& Gallus, J. (2013). Subjective Well-Being and Policy. Topoi, 32(2), 207-212.

Frey, B. S., \& Stutzer, A. (2000). Happiness prospers in democracy. Journal of Happiness Studies, 1, 79-102.

Frey, B. S., \& Stutzer, A. (2002a). Happiness and Economics: How the economy and institutions affect well-being. Princeton: Princeton University Press.

Frey, B. S., \& Stutzer, A. (2002b). What Can Economists Learn from Happiness Research? Journal of Economic Literature, 40, 402-435.

Gamson, W. A. (1992). The social psychology of collective action. In A. Morris, \& C. Mueller, Frontiers of social movement theory (p. 53-76). New Haven: Yale University Press.

García-Ramírez, M., Manuel, L., Paloma, V., \& Hernández-Plaza, S. (2011). A liberation psychology approach to acculturative integration of migrant populations. American Journal of Community Psychology, 47(1-2), 86-97.

Gray, M., \& Caul, M. (2000). Declining voter turnout in advanced industrial democracies, 1950 to 1997. Comparative Political Studies, 33, 1091-1121.

Grinde, B. (2012). The biology of happiness. Springer Netherlands.

Halpern, D. (2005). Social capital. Cambridge: Polity.

Inghilleri, P. (1999). From Subjective Experience to Cultural Change. New York: Cambridge University Press.

Innes, E. J. (1990). Disappointment and Legacies of Social Indicators. Journal of Public Policy(9), 429-432.

Jackson, S. A., \& Marsh, H. W. (1996). Development and validation of a scale to measure optimal experience: The flow state scale. Journal of Sport \& Exercise Psychology, 18, 17-35. 
Kagan, C. (2006). Making a difference: Participation and well-being. Liverpool: New Start Publishing. Kallis, G. (2011). In defence of degrowth. Ecological Economics, 70(5), 873-880.

Kashdan, T. B., Biswas-Diener, R., \& King, L. A. (2008). Reconsidering happiness: the costs of distinguishing between hedonics and eudaimonia. The Journal of Positive Psychology, 3(4), 219-233.

Kasser, T. (2006). Materialism and its alternatives. In M. Csikszentmihalyi, \& I. Csikszentmihalyi (Eds.), A life worth living: Contributions to positive psychology (p. 200-214). Oxford: Oxford University Press.

Kasser, T. (2011). Ecological challenges, materialistic values, and social change. In R. Biswas-Diener, Positive Psychology as Social Change (p. 89-108). Springer Netherlands.

Kennedy, R. F. (1968, Marzo 18). Tratto il giorno Ottobre 7, 2010 da www.glaserprogress.org: http:// www.glaserprogress.org/program_areas/pdf/Remarks_of_Robert_F_Kennedy.pdf

Kenny, C. (1999). Does growth cause happiness, or does happiness cause growth? Kyklos, 52(1), 3-25.

Keyes, C. L. (2003). Complete mental health: An agenda for the 21th century. In C. L. Keyes, \& J. Haidt, Flourishing. Positive psychology and the life well-lived (p. 293-312). Washington DC: American Psychological Association Press.

Keyes, C. L. (2006). The subjective well-being of America's youth: Toward a comprehensive assessment. Adolescent \& Family Health, 4(1), 3-11.

Keyes, C. L., \& Annas, J. (2009). Feeling good and functioning well: distinctive concepts in ancient philosophy and contemporary science. The Journal of Positive Psychology, 4(3), 197-201.

Kim-Prieto, C., Diener, E., Tamir, M., Scollon, C., \& Diener, M. (2013). Integrating the Diverse Definitions of Happiness: A Time-Sequential Framework of Subjective Well-Being. In A. Delle Fave, The Exploration of Happiness. Present and Future Perspectives (p. 47-75). Dordrecht: Springer Netherlands.

King, L. A., Eells, J. E., \& Burton, C. M. (2002). The good life, broadly and narrowly considered. In P. A. Linley, \& S. Joseph, Positive psychology in practice (p. 35-52). New York: Wiley.

Klar, M., \& Kasser, T. (2009). Some Benefits of Being an Activist: Measuring Activism and Its Role in Psychological Well-Being. Political Psychology, 30(5), 755-777.

Kuznets, S. (1934). National Income, 1929-1932. 73rd US Congress, 2nd session, Senate document no.124, pag. 7.

Lane, R. E. (1996). Quality of life and quality of persons: A new role for government? In A. Offer (Ed.), In pursuit of the quality of life (p. 256-293). New York: Oxford University Press.

Latouche, S. (2007). Degrowth: an electoral stake? International Journal of Inclusive Democracy, 3(1), 14-18.

Lucas, R. E. (2001). Pleasant affect and sociability: Towards a comprehensive model of extraverted feelings and behaviors. Dissertation Abstracts International, 61(10-B), 5610, UMI No. AAl9990068.

Lyubomirsky, S., Sheldon, K. M., \& Schkade, D. (2005). Pursuing happiness: The architecture of sustainable change. Review of General Psychology, 9, 111-131.

Mancall, M. (2004). Gross national happiness and development: an essay. In K. Ura, \& K. Galay, Gross national happiness and development (p. 1-54). Thimpu: Centre for Bhutan studies.

Mannarini, T., Fedi, A., \& Trippetti, S. (2010). Public involvement: How to encourage citizen participation? Journal of Community and Applied Social Psychology, 262-274.

Meier, S., \& Stutzer, A. (2008). Is volunteering rewarding in itself? Economica, 75, 39-59.

Noll, H.-H. (2004). Social indicators and quality of life research: Background, achievements and current trends. In N. Genov (Ed.), Advances in sociological knowledge. Over half a century (Vol. I, p. 151-181). Wiesbaden: VS Verlag fuer Sozialwissenschaften.

Noll, H.-H., \& Zapf, W. (1994). Social Indicators Research: Societal Monitoring and Social Reporting. In I. Borg, \& P. P. Mohler (Eds.), Trends and Perspectives in Empirical Social Research (p. 1-16). Berlin/New York: de Gruyter. 
Obst, P., Smith, S. G., \& Zinkiewicz, L. (2002). An exploration of sense of community, part 3: Dimensions and predictors of psychological sense of community in geographical communities. Journal of Community Psychology, 30(1), 119-133.

OECD. (1976). Measuring Social Well-Being: A Progress Report on the Development of Social Indicators. Paris: OECD.

Omoto, A. M., \& Snyder, M. (1995). Sustained helping without obligation: motivation, longevity of service, and perceived attitude change among AIDS volunteers. Journal of personality and social psychology, 68(4), 671-686.

Pavot, W., \& Diener, E. (2004). Findings on Subjective Well-Being: Applications to Public Policy, Clinical Interventions, and Education. In P. A. Linley, \& S. Joseph (Eds.), Positive Psycholgy in Practice (p. 679-692). Hoboken, N): John Wiley \& Sons.

Prilleltensky, I. (2008). Migrant well-being is a multilevel, dynamic, value dependent phenomenon. American Journal of Community Psychology, 42(3-4), 359-364.

Prilleltensky, I., Nelson, G., \& Peirson, L. (2001). The role of power and control in children's lives: An ecological analysis of pathways toward wellness, resilience and problems. Journal of Community \& Applied Social Psychology, 11(2), 143-158.

Putnam, R. D. (2000). Bowling Alone: The Collapse and Survival of American Community. New York: Simon and Schuster.

Rapley, M. (2003). Quality of life research. London: Sage Publications.

Ryan, R. M., \& Deci, E. L. (2001). On happiness and human potentials: a review of research on hedonic and eudaimonic well-being. Annual Review of Psychology, 52, 141-166.

Ryan, R. M., \& Huta, V. (2009). Wellness as healthy functioning or wellness as happiness: the importance of eudaimonic thinking (response to the Kashdan et al. and Waterman discussion). The Journal of Positive Psychology, 4(3), 202-204.

Ryff, C. D., \& Keyes, C. L. (1995). The structure of psychological well-being revisited. Journal of personality and social psychology, 69(4), 719-727.

Smetana, J. G., Campione-Barr, N., \& Metzger, A. (2006). Adolescent development in interpersonal and societal contexts. Annual Review of Psychology, 57(1), 255-284.

Stutzer, A., \& Frey, B. S. (2006). Political participation and procedural utility: An empirical study. European Journal of Political Research, 45, 391-418.

Thin, N. (2011). Socially Responsible Cheermongery: On the Sociocultural Contexts and Levels of Social Happiness Policies. In R. Biswas-Diener, Positive Psychology as Social Change (p. 33-49). Springer Netherlands.

Veenhoven, R. (1991). Questions on happiness: classical topics, modern answers, blind spots. In F. Strack, M. Argyle, \& N. Schwarz (Eds.), Subjective wellbeing (p. 7-26). Oxford: Pergamon Press.

Veenhoven, R. (1996). Happy Life-expectancy: a comprehensive measure of quality-of-life in nations. Social Indicators Research, 39, 1-58.

Veenhoven, R. (2000). Freedom and Happiness: a comparative study in fouty-four nations in the early 1990s. In E. Diener, M. Eunkook, \& M. Suh (Eds.), Culture and Subjective well-being (p. 257-288). Cambridge, MA: MIT Press.

Vogel, J. (1989). Social Indicators: A Swedish Perspective. Journal of Public Policy, 9(4), 439-444.

Wallace, C., \& Pichler, F. (2009). More participation, happier society? A comparative study of civil society and the quality of life. Social indicators research, 93(2), 255-274.

Wandersman, A., \& Florin, P. (2000). Citizen participation and community organizations. In J. Rappaport, \& E. Seidman, Handbook of community psychology (p. 247-272). New York: Kluwer Academic/Plenum Press.

Waterman, A. S. (2008). Reconsidering happiness: a eudaimonist's perspective. The Journal of Positive Psychology, 3(4), 234-252. 
Waterman, A. S., Schwartz, S., \& Conti, R. (2008). The implications of two conceptions of happiness (hedonic enjoyment and eudaimonia) for the understanding of intrinsic motivation. Journal of Happiness Studies, 9(1), 41-79.

Williams, S., \& Shiaw, W. T. (1999). Mood and organizational citizenship behavior: The effects of positive affect on employee organizational citizenship behavior intentions. Journal of Psychology, 133, 656-668. 